\title{
THE SURPRISING FINDING THAT "CULTURAL WORLDVIEWS" DON'T EXPLAIN PEOPLE'S VIEWS ON GUN CONTROL
}

\author{
GERTRUd M. FREMLing ${ }^{\dagger} \&$ JOHN R. LOTT, JR. ${ }^{\dagger \dagger}$ \\ Using the General Social Survey, Kahan and Braman show that "cullural \\ zorldviezus" only explain about 1.6 percentage poinls of people's viezus on gun \\ control. Assuming that their indexes properly measure these "cultural world- \\ vieaus," the results are very striking and surprising. In addition, $92 \%$ of the \\ variation in people's views isn't exen explained zuhen all the factors that they ar- \\ count for are included. While they don't test the hypothesis, it is very conceivable \\ that some of the $92 \%$ can be explained by what information people receive. If so, \\ the returns to research could be quite large.
}

\section{INTRODUCTION}

Do people's values and political perspectives influence their positions on gun control? Certainly, there is no doubt about it. . But facts must also matter. To say that only people's values matter seems oddly circular, because it fails to explain the origin of these values. If values do not come from facts that we encounter-either through our own experiences, those we learn from other individuals, or from more evidence of a scientific nature-where would they come from? Are values the result of pure randomness? Not likely. There must be some contributing factors. Are values the result of innate human instinct? Possibly some. But if one were to argue that attitudes originate from religion, politics, or moral philosophy, would not these attitudes ultimately originate from the perceptions held by prophets, politicians, and philosophers? And these perceptions would not be based on reason alone, but on these individuals' experiences as well as on experiences and facts related to them by other individuals.

While Kahan and Braman's article focuses on gun control, their claim that empirical work is of little value ${ }^{1}$ must surely apply to other issues. Yet, the importance of facts in altering views seems undeni-

' Ph.D. in Economics, University of California, Los Angeles.

${ }^{i \dagger}$ Resident Scholar, American Enterprise Institute.

'See Dan M. Kahan \& Donald Braman, More Slatislics, Lees Persuasion: A Cultural Theory of Gun-Risk Perceptions, 151 U. PA. L. REV. 1291, 1317-18 (2003) (arguing that "narrowly consequentialist measures" offer an inadequate explanation of public risk perceptions). 
able. Surely the failure of communism and its fall in the former Soviet Union and Eastern Europe affected views on government ownership of production. Today few economists deny that price controls cause shortages." The vast majority also believe that increasing the money supply is the primary reason for inflation." The consensus is so overwhelming today that it is hard to remember how contested these ideas were just four or five decades ago.

Scientific discoveries reflect another form of empirical work that has obviously revolutionized our thinking about the universe and the place and role humans occupy. Science has generated much bigger upheavals than mere "attitudes" about social issues. For example, as evidence gathered that the Earth circled the sun, we could no longer view ourselves as being the center of the universe. Likewise, the concept of evolution and the evidence behind it profoundly changed our views on human nature itself.

Kahan and Braman should be lauded for attempting to provide empirical evidence using data obtained from the General Social Survey (GSS). Data gathering and statistical analysis should be done more, not less, frequently. Of course, that is our perspective. The irony is that they try to use empirical evidence to show that empirical evidence doesn't matter.

If found correct, their bold hypothesis would surely shake up academia and political debate. Philosophy and religion, which are more heavily based on reasoning and ethics, would increase in prominence, while economics and, in particular, statistics would become less relevant. Unfortunately for them, their results do not support their claims. Indeed, as we demonstrate, Kahan and Braman's results show the very opposite of what they hope.

\footnotetext{
"A survey of economists in 1990, for example, indicated that $93 \%$ either "agree" or "generally agree" that "[a] ceiling on rents reduces the quantity and quality of housing available." Richard M. Alston et al., Is There a Consensus Among Economists in the 1990's?, 82 Am. ECON. Rliv. 203, 204 tbl. 1 (1992).

"A survey of economists in 1990 indicated that $70 \%$ either "agree" or "generally agree" that "[i]nflation is primarily a monetary phenomenon." Id. at 204.

"Seg Milton Friediman \& George J. Stigler, Roofs or Ceillngs? The Current HOUSING PROBLEM (1946) (explaining the overlooked idea that price ceilings are the cause of housing shortages); see also MILTON FRIEDMAN, MONEY MISCHIEF: EPISODES IN MONETARY HISTORY 193-204 (1992) (dispelling traditionally advanced explanations that nonmonetary phenomena such as business greed, international economic forces, and low productivity are causes of inflation).
} 


\section{THEIR EVIDENCE}

Kahan and Braman reach two closely related conclusions: (1) "individuals' attitudes toward gun control are derivative of the type of social order they prize"; and (2) "those interested in resolving the gun debate should turn their attention away from quantifying the consequences of gun control." These conclusions are based on the two regressions reported in Table 1 of their article.

Their reasoning points to the statistically significant coefficients that they obtain for their "hierarchy-egalitarianism" and "individualism-solidarism" indexes. ${ }^{8}$ They are indeed correct that these coefficients are statistically significant. But statistical significance is not the same as importance: it is incorrect to claim that these variables explain much of people's views on gun control. The indexes developed by Kahan and Braman increase our ability to predict people's opinions on gun control by merely 1.6 percentage points (the difference in the two $R^{2}$ s, equal to .08 minus .064 , representing the change in how much of the variation in people's opinions on gun control can be explained by adding these two variables).' In other words, cultural attitudes explain less than $2 \%$ of attitudes on guns. (Our guess is that if Kahan and Braman's data set allowed a more precise control of stateor area-code-fixed effects, they would find an even smaller percentage of the variation explained by their two desired control variables, and the statistical significance might well drop too.) Thus, Kahan and Braman prove the opposite of what they intended. Instead of demonstrating that people's views of social order explain a lot of the variation in positions on gun control, they show that these views matter very little.

Possibly, the unexplained $92 \%$ of the variation in people's views (the remainder after factoring the $.08 R^{2}$ variable reflecting people's opinions on gun control that can be explained) could be completely due to randomness. Yet, it is very conceivable that some of the $92 \%$ figure could be explained by what information people receive. The central problem here is that Kahan and Braman actually do not test

"Kahan \& Braman, supra note 1, at 1323.

"Id. at 1.324 (emphasis omitted).

${ }^{7}$ Id. at 1.306 tbl.1.

"See id. at 1302-04 (describing the hierarchy-egalitarianism and individualismsolidarism scales and the inclinations of survey respondents each scale aims to measure).

Id. at 1306 tbl. 1 . 
whether information matters. They test whether attitudes matter. Obviously, there is no logic that rules out that both matter.

To solve this problem, they need a measure of what information people receive. Perhaps they could include a dummy variable such as whether or not respondents have read More Guns, Less Crime, ${ }^{10}$ seen certain news shows, or seen some major news event. If we identify a reasonable variable of that nature and show it to be statistically significant, then we can conclude that information matters. At that point, we could compare relative magnitudes: does the influence stemming from "attitudes" exceed that stemming from "information"? (Unfortunately, the task would probably encounter great complexity due to collinearity between the two explanatory variables-the information channels we seek out also depend on our preexisting attitudes.) However, without showing the statistical significance of information, its importance remains unknown.

Another theoretical problem we have with Kahan and Braman's conclusions is their lack of consideration for the potential of empirical evidence to determine whether gun control helps people obtain their social goals. For example, suppose that research showed that gun ownership was consistent with egalitarianism. Right-to-carry laws allow the most vulnerable in society to protect themselves: those most vulnerable to crime (the poor who live in high crime urban areas); the physically weak (women and the elderly); and those who face racial or other hatreds (African Americans and homosexuals)." These are the exact segments of society for which egalitarians exhibit concern. ${ }^{12}$ Even if people only care about social values, don't they care about whether the regulations that they propose help them obtain their goals?

10 See generally JOHN R. LOTT, JR., MORE Guns, Less CRIME (2d ed. 2000) (presenting evidence indicating that gun control does not save lives).

${ }^{11}$ See id. at 183-84 ("[T] hose who are relatively weaker physically (women and the elderly) and those who are most likely to be crime victims (blacks and those living in urban areas) tend to benefit the most from the passage of right-to-carry laws."). For a discussion of the general beneficial protections of right-to-cany laws, see $i d$. at 97-116.

${ }_{12}^{12}$ See Kahan \& Braman, supra note 1, at 1303 (defining egalitarianism as in "opposition to social differentiation and . . toleran [t] of deviance"). 


\section{WHAT IS ECONOMICS?}

Kahan and Braman dismiss economics on a couple of fronts, both on the grounds that incentives don't matter ${ }^{13}$ as well as for economics' supposed inability to explain how people's views change (or how people learn). ${ }^{14}$

\section{A. Do Incentives Matter?}

[If] individuals behave like rational utility maximizers ...., one would expect variation in violent crime-and hence variation in the likelihood that guns will be used for violent purposes-to explain a substantial amount of the variation in attitudes toward gun control.

This problem is more complicated than discussed here by Kahan and Braman. Whether increased crime rates could lower or increase support for gun control depends upon individuals' conceptions of the relationship between gun control and crime. With people holding both views, it is not clear which effect will dominate or even that there will be an effect systematic enough to be statistically significant.

Yet it seems indisputable that, in general, incentives matter. Whether the question involves the deterrence of criminals through higher arrest and conviction rates, longer prison sentences, or increasing penalties, they all deter criminals." This is also proven by the different international rates of so-called "hot burglaries," where residents

${ }^{13}$ See id. at 1312 (questioning the impact of empirical information-for example, information concerning crime rates and the deterrent value of gun ownership-on attitudes toward gun control).

${ }^{14}$ See ill at $1312-14$ (criticizing economic hypotheses accounting for how individuals weigh evidence and thus draw conclusions from it).

If. Id. at 1312 .

${ }^{16}$ For some recent articles discussing the deterrent effects of gun ownership, see William Alan Bartley \& Mark A. Cohen, The Effect of Concealed Weapons Latus: An Lxtreme Bound Analysis, 36 ECON. INQUIRY 258, 258-59 (1998); Stephen G. Bronars \& John R. Lott, Jr., Criminal Deterrence, Geographic Spillovers, and Right-to-Carry Laws, 88 AM. ECON. REv. 475, 475 (1998); John R. Lott, Jr. \& John E. Whitley, Safe-Storage Gun Larus: Accidental Dealls, Suicides, and Crime, 44 J.L.. \& ECON. 659, 677-81 (2001); Tomas B. Marvell, The Impact of Banning Juvenile Gun Possession, 44 J.L. \& ECON. 691, 700-11 (2001); Carlisle E. Moody, Testing for the Effects of Concealed Weapons Latus: Specification Lrrors and. Robustness, 44 J.L. \& ECON. 799, 802-04 (2001); David B. Mustard, The Impact of Gun Latus on Police Deaths, 44 J.L. \& ECON. 635, 648-49 (2001); David E. Olson \& Michael D. Maltz, Right-10-Carry Concealed Weapon Latus and Homicide in Large U.S. Counties: The Effect on Weapon Types, Victim Characteristics, and Victim-Offender Relationships, 44 J.L. \& ECON. 747, 758-67 (2001); Florenz Plassmann \& T. Nicolaus Tideman, Does Right to Carry Concealed Handguns Deter Countable Crimes? Only a Count Analysis Can Say, $44 \mathrm{~J} . \mathrm{L}$. \& ECON. 771, 783-88 (2001). 
are at home when the criminals strike. ${ }^{17}$ Fifty-nine percent of the burglaries in Britain, which has tough gun control laws, are "hot burglaries." $^{\prime \prime}$ By contrast, the United States, with laxer restrictions, has a hot-burglary rate of only $13 \% .^{19}$ Consistent with this, surveys of convicted felons in America reveal that during burglaries they are much more worried about encountering armed victims than they are about running into the police. ${ }^{20}$ This fear of potentially armed victims causes American burglars to spend more time than their foreign counterparts "casing" a house to ensure that nobody is home. Felons frequently comment in these interviews that they avoid late-night burglaries because "that's the way to get shot."21

Also, despite the suggestions of Kahan and Braman, ${ }^{22}$ people do indeed respond to the specific threat of crime with respect to gun attitudes and behavior. Individuals living in more crime-prone communities, as well as individuals who have used guns in the past for selfdefense, are more likely to store their guns unlocked and loaded. ${ }^{23}$

\section{B. Can Economics Explain How People Learn?}

[T] he "rational weigher" hypothesis seems to beg the most important question: what determines how much weight individuals assign to any given piece of evidence. . . ?

Economics has a lot to say about how people learn. The same tools economics uses to explain why criminals commit fewer crimes as deterrence increases apply equally to learning patterns. We offer two

${ }^{17}$ For example, Kopel provides intemational evidence on hot-burglary rates. See David B. Kopel, Lawyers, Guns, and Burglars, 43 ARlz. L. REV. 345, 361 (2001) (finding that the "American violent crime rate is significantly lower . . . because American burglars are much less likely than Canadian burglars to enter an occupied home").

Id. at 348 .

1:1 Id. at 360 .

20 James D. Wrigitt \& Pliter H. Rossi, Armed and Considered dangerous: A SuRveY OF Felons AND THEIR Firearms 145 (1986).

21 James Wright and Peter Rossi interviewed felony prisoners in ten state correctional systems and found that $56 \%$ said that criminals would not attack a potential victim known to be armed. I $d$. They also found evidence that criminals in those states with the highest levels of civilian gun ownership worried the most about armed victims. Id. at I5I.

${ }^{22}$ See Kahan \& Braman, supra note 1, at 1312 ("[N] either actual crime rates, perceived crime rates, prior victimization, nor fear of victimization strongly correlates with public opinion toward gun control.").

2:3 JOHN R. LOTT, JR., THE BIAS AGAINST GUNS 176 (2003).

${ }^{24}$ Kahan \& Braman, supra note 1, at 1312 (emphasis omitted). 
examples. First, economics maintains that as the cost of accessing and absorbing different types of information, the types of views and values held by people also change. The principle even explains how and why governments in many countries have gone to great lengths to control the information that citizens receive, e.g., through schooling and through the media. ${ }^{25}$ Second, economics recognizes that individuals conceptually experience difficulty setting up causal hypotheses. ${ }^{20}$ Many people fail to notice certain regularities, something that in past work we have labeled "the bias toward zero."

Of course, even if people do not fully appreciate factual relationships, as we just argued, it could still be possible that people almost exclusively rely on fact, however imperfect. Furthermore, as a corollary point, people's possible reliance on fact suggests that basic attitudes in other respects do not matter all that much (or can be explained, in turn, by facts in other areas).

Reality is a dynamic, complicated process, and it is very likely that attitudes are, in some sense, "important" in explaining how people act. This assertion is difficult to prove statistically. The open question, which really was not tested in Kahan and Braman's article, is whether experiences and facts also play a role and whether these are even more important than the cultural attitudes they exalt.

\section{CONCluSiON}

It is very interesting that Kahan and Braman find that attitudes on guns are so little explained by attitudes in other areas. Merely 1.6 percentage points of attitudes toward gun control can be attributed to attitudes in other areas. This is surprising since the gun debate is typically viewed as politically polarized, as a right-wing versus left-wing issue. But, perhaps, many issues are simply defined in the media by

25. See John R. Lott, Jr., An Explanation for Public Provision of Schooling: The Importance of Indoctrination, 33 J.L. \& ECON. 199, 201 (1990) (arguing that "schooling lowers the cost of wealth transfers by instilling the right views"); John R. Lott, Jr., Public Schooling, Indoctrination, and Totalitarianism, 107 J. POL. ECON. S127, S128 (1999) (claiming that "[g]overnments have gone to great lengths to instill desired values in children," and exploring "the characteristics of governments that have the greatest returns to indoctrination, are more likely to own the media, and are in fact making larger investments in public education").

26. See Gertrud M. Fremling \& John R. Lott, Jr., The Bias Touatd Zero in Identifying Relationships: Reply to Kennedy, 37 ECON. INQUIRY 385, 385 (1999) ("Individual actors are sometimes quite clueless as to an economic problem, failing to understand that two (or more) variables are related.").

${ }^{27}$ Id. 
what organizations carry what messages. The views by any given individual might be less "coherent" across issues than are the views presented by a particular organization.

We think Kahan and Braman should revise their conclusion and take credit for this interesting finding. 